\title{
„To já jsem matkou svého otce": Ženský princip a staroegyptské náboženské prvky v gnósi
}

\author{
MARTIN PEHAL
}

Jak pregnantně formuloval G. Fowden ve vztahu ke zkoumání „staroegyptských" ${ }^{\text {"1 }}$ kořenů hermetické tradice, ${ }^{2}$ gnósi je potřeba vnímat jako součást velice synkretického prostředí pozdní antiky, v němž zcela zásadní úlohu hrál Egypt. ${ }^{3}$ Ve svém příspěvku se pokusím obhájit názor, že vedle intelektuálních a rituálních tradic židovské, křestanské a řecké, jež jsou běžně identifikovány jako inspirační zdroje gnostických systémů, se v gnostických spisech setkáváme i s prvky autochtonního staroegyptského náboženství. Toto propojení totiž poskytuje srozumitelný interpretační rámec pro některé dílčí gnostické motivy, respektive přímo celé skladby, např́iklad (Paní) ${ }^{4}$ hromu: Dokonalá mysl [Hrom] (kodex z Nag Hammádí

* Tato práce vznikla za podpory projektu „Kreativita a adaptabilita jako předpoklad úspěchu Evropy v propojeném světě“ (CZ.02.1.01/0.0/0.0/16_019/0000734), financovaného z Evropského fondu pro regionální rozvoj, a dále za podpory programu Univerzitní výzkumná centra UK č. 204053. Za cenné připomínky velice děkuji Marku Dospělovi, Zuzaně Vítkové, Lucii Valentinové, Radku Chlupovi a anonymním recenzentům. Za pečlivou redakční práci děkuji Michaele Ondrašinové.

1 Adjektivum „staroegyptský“ v této studii neurčuje primárně stáří, ale je užíváno jako obecné označení náboženských textů a kulturních koncepcí, které vycházejí z autochtonní ,staroegyptské“ tradice, byt se v některých případech jedná o prameny relativně pozdní.

2 Garth Fowden, The Egyptian Hermes: A Historical Approach to the Late Pagan Mind, Princeton: Princeton University Press 1993, 155.

3 Pro shrnutí diskuse o egyptských kořenech hermetismu viz Radek Chlup, Corpus Hermeticum, Praha: Herrmann a synové 2007, 39-42. Existuje ovšem i badatelská linie, jež mezi starým a křestanským Egyptem naprosto žádnou návaznost nevidí a jakékoliv interpretační snahy tímto směrem kategoricky odmítá, např. Ewa Wipszycka, ,Le nationalisme a-t-il existé dans l'Egypte byzantine?““, Journal of Juristic Papyrology 22, 1992, 83-128.

4 V tomto označení následuji Zuzanu Vítkovou, která se tak snaží zachovat femininní charakter této postavy. Viz Zuzana Vítková, „Hrom: Dokonalá mysl [NHC VI/2, 13,121,32]“, in: Wolf B. Oerter - Zuzana Vítková (eds.), Rukopisy z Nag Hammádí II, Praha: Vyšehrad 2009, 39-60. 
[NHC] VI,2, viz níže), které je obtížné interpretovat tradičním prizmatem. Ústředním motivem, kolem něhož svou argumentaci vystavím, bude analýza podobné funkce a působnosti ženských postav v gnostických textech na straně jedné a ve staroegyptských písemných pramenech a rituální praxi (zastoupené kultem tzv. Velkých bohyní) na straně druhé.

Má argumentace bude postupovat v následujících krocích. Nejprve shrnu dosavadní bádání, a to jak z hlediska společných obecných rysů těchto myšlenkových a symbolických systémů, tak i z hlediska dílčích motivů. $\mathrm{Z}$ tohoto přehledu vyplývá, že interpretace gnostického materiálu přes působnost ženských postav ve vztahu ke staroegyptským vzorům nebývá přiliš obvyklá, pokusím se však ukázat, že je ze všech případných podobností nejrelevantnější. Shrnutí třicáté kapitoly díla Adversus haereses [AH] $\mathrm{z}$ pera raně křestanského heresiologa Eirénaia z Lyonu, jež srovnám se staroegyptským kosmogonickým mýtem dochovaným v chrámu boha Chonsua v Karnaku, poslouží jako rozvedení komparativních snah předchozích autorů a vztáhne ústřední téma působnosti ženských božstev $\mathrm{k}$ dalším relevantním motivům. Stručná charakteristika role ženských postav v gnostickém i staroegyptském materiálu následně ukáže, že nejdůležitějším spojujícím motivem je jejich prostředkující role ve stvořitelském procesu, charakterizovaná ambivalentní či přímo paradoxní mocí, jíž disponují (jsou v celém procesu ústřední, ale zároveň jaksi marginalizované). Ta přitom vyplývá z jejich vztahu vzájemné stvořenosti s mužským stvořitelem. Na závěr se pokusím nastínit mechanismus možného působení staroegyptských kultů takzvaných Velkých bohyní na gnostické komunity, včetně spekulace ohledně důvodu zdůrazňování androgynních/gynandrických aspektů stvořitelských ženských postav.

Na tomto místě je také třeba zdůraznit, že text nemá ambici vstoupit do debaty, která byla živá zejména ve druhé polovině 20. století a jež řešila otázku (mimo/před)křestanského charakteru nejrůznějších gnostických směrů. ${ }^{5}$ Mým cílem je ukázat, že některé z motivů př́itomných v gnostickém myšlení $\mathrm{v}$ podobě, $\mathrm{v}$ jaké se nám dochovaly $\mathrm{v}$ textových pramenech, dávají smysl právě ve vztahu k původnímu staroegyptskému náboženské-

5 Pro vyhodnocení zejména starší literatury viz např. Edwin M. Yamauchi, Pre-Christian Gnosticism: A Survey of the Proposed Evidences, Grand Rapids: Baker Book House ${ }^{2}$ 1983, 181-249. Mnozí autoři obhajující mimo/před-křestanské kořeny gnosticismu mohli být vedeni jakousi apologetickou snahou oddělit křestanství od těchto velice synkretických myšlenkových a rituálních systémů. Velice sofistikovanou obhajobu „gnosticismu“ coby vnitřně strukturovaného systému předkládá např. Birger A. Pearson, Gnosticism and Christianity in Roman and Coptic Egypt, New York: T and T Clark International 2004; contra: Michael A. Williams, Rethinking „Gnosticism “: An Argument for Dismantling a Dubious Category, Princeton: Princeton University Press 1999; Karen L. King, What is Gnosticism?, Cambridge, MA : Harvard University Press 2003. 
mu prostředí. Staroegyptské kulty byly totiž aktivní několik prvních staletí po Kristu, tedy souběžně s existencí křestanských a gnostických tradic. ${ }^{6}$ Pokusit se nalézt odpověd' na otázku po jejich vzájemném vztahu je proto důležité.

\section{Historický a kulturní kontext}

Jedním z nejdůležitějších obchodních a intelektuálních center celého Středomoří v době rozvoje gnostických systémů byla egyptská Alexandrie - mimo jiné sídlo ptolemaiovské faraonské dynastie a domov významné židovské diaspory (Septuaginta, řecký překlad hebrejských posvátných textů, údajně vznikala na př́ikaz Ptolemaia II. od 3. stol. př. Kr.). Z Alexandrie prý pocházeli např́iklad slavní „,heretici“ Basilides a Valentinus, proti nimž jsou namířeny polemické spisy raných křestanských apologetů, zejména Eirénaia (Adversus haereses [AH], vznik cca 185 po Kr.), ale také Hippolyta, Epifania, Tertulliana, Órigena a dalších. ${ }^{7}$ Významný vliv na formování gnóse měla novoplatónská filosofie a řecká učenost obecně (Klémens Alexandrijský, Órigenés a další). Plótínos, jeden z klíčových reprezentantů novoplatonismu, pocházel z hornoegyptské Lykopole (arab. Asjútu). Badatelé proto rozeznávají celou škálu obousměrných paralelismů, případně výpůjček mezi gnósí a nejrůznějšími filosofickými, náboženskými a myšlenkovými tradicemi prvních staletí (za všechny zmiňme např́iklad fenomén tzv. řeckých magických papyrů $\left.{ }^{8}\right)$. Z tohoto hlediska je možné gnósi vnímat jako typický produkt helénistického espritu. ${ }^{9}$

6 Tuto koexistenci je možné jednoduše doložit pro chrámový komplex bohyně Esety na ostrově Fílé, kde byly egyptské kulty aktivní ještě během většiny šestého století po Kristu, a působily tak v oblasti paralelně s křestanskou koptskou církví po několik staletí (biskupský stolec byl v oblasti prvního kataraktu ustaven během první poloviny čtvrtého století), viz např. Jitse H. F. Dijkstra, Philae and the End of Ancient Egyptian Religion: A Regional Study of Religious Transformation (298-642 CE), Leuven: Peeters 2008.

7 Pro analýzu návaznosti egyptského křestanství (koptské církve) na staroegyptské motivy a tradice viz přehledovou studii Heike Behlmer, „Ancient Egyptian Survivals in Coptic Literature: An Overview“, in: Antonio Loprieno (ed.), Ancient Egyptian Literature: History and Forms, Leiden - New York - Köln: Brill 1996, 567-590. Contra: viz např. David Frankfurter, „Amente Demons and Christian Syncretism“, Archiv für Religionsgeschichte 14/1, 2013, 83-102, který ve vztahu ke koptské démonologii hájí podle něj pravděpodobnější vliv židovské apokalyptické literatury.

8 Hans D. Betz (ed.), The Greek Magical Papyri: Including the Demotic Spells, Chicago - London: University of Chicago Press ${ }^{2} 1992$.

9 Zásadní studií o Egyptě v helénistické době je Ian S. Moyer, Egypt and the Limits of Hellenism, Cambridge, NY: Cambridge University Press 2011. 


\section{Přehled dosavadního bádání}

Myšlenku staroegyptského původu některých gnostických koncepcí formuloval poprvé již na konci 19. století É. C. Amélineau. ${ }^{10}$ Ačkoliv tehdy ještě nebyly $\mathrm{k}$ dispozici texty $\mathrm{z}$ Nag Hammádí (objevené až v roce 1945), ${ }^{11}$ Amélineauovy závěry jsou v mnohém případné, jak je vidět i z práce dalších badatelů. ${ }^{12}$

\subsection{Symbolicky systémové podobnosti}

Celostní uchopení dané problematiky neexistuje. ${ }^{13}$ První pokus o podrobné srovnání pochází od D. Parrotta, ${ }^{14}$ jenž poukázal na inspiraci staroegyptskými kosmogonickými koncepcemi (konkrétně heliopolským mýtem o stvoření) ${ }^{15}$ v rámci spisu Požehnaný Eugnóstos (NHC III,3; V,1) a potažmo i v jeho křestanské variantě Moudrost Ježišse Krista (NHC III,4;

10 Émile C. Amélineau, Essai sur le gnosticism égyptien: Ses développements et son origine égyptienne, Paris: Leroux 1887.

11 Pro kritické překlady do češtiny a komentáře viz Wolf B. Oerter - Petr Pokorný (eds.), Rukopisy z Nag Hammádí I, Praha: Vyšehrad 2008; Wolf B. Oerter - Zuzana Vítková (eds.), Rukopisy z Nag Hammádí II, Praha: Vyšehrad 2009; Wolf B. Oerter (ed.), Rukopisy z Nag Hammádí III, Praha: Vyšehrad 2010; Wolf B. Oerter - Zuzana Vítková (eds.), Rukopisy z Nag Hammádí IV, Praha: Vyšehrad 2016; Wolf B. Oerter - Zuzana Vítková (eds.), Rukopisy z Nag Hammádí V, Praha: Vyšehrad 2018.

12 Někteří se však stavějí proti rozeznávání zásadních paralel mezi těmito tradicemi, viz např. Jean Doresse, The Secret Books of the Egyptian Gnostics: An Introduction to the Gnostic Coptic Manuscripts Discovered at Chenoboskion: With an English Translation and Critical Evaluation of the Gospel according to Thomas, trans. Philip Mairet, London: The Viking Press 1960, 272-275; Claas J. Bleeker, „,The Egyptian Background of Gnosticism", in: Ugo Bianchi (ed.), Le origini dello gnosticismo: Colloquio di Messina 13-18 Aprile 1966, Leiden: Brill 1967, 229-237. Bleeker zakládá svou pochybnost na předpokladu, že kořeny gnóse neleží v Egyptě, ale v Íránu, případně v Sýrii (ibid., 230).

13 Pro jakousi všehochut možných paralel viz Gertrude Thausing, „Altägyptische Gedanken in der Gnosis“, Kairos 15, 1973, 116-122. Určitou „predispozici“ staroegyptského náboženského systému ke gnostizaci rozebírá Walter Beltz, „Ägyptische Prädispositionen für die Gnosis“, Hallesche Beiträge zur Orientwissenschaft 5, 1983, 71-88.

14 Douglas M. Parrott, „Gnosticism and Egyptian Religion“, Novum Testamentum 29, 1987, 73-93.

15 Héliopolská tradice popisuje objevení se prvotního světla, boha slunce Re, a povstání tzv. Devatera (Enneády: Atum [,„Celostný/V-sobě-konečný“] $\rightarrow$ Šu [vzduch] a Tefnut [vlhkost] $\rightarrow$ Geb [země] a Nut [nebe] $\rightarrow$ Usir a Eset, Sutech a Nebthet), v jehož rámci je někdy jako desátý člen uváděn Hor, syn Usira a Esety, který byl ztotožněn s vládnoucím faraonem, podobně jako byl s Usirem ztotožněn faraon zesnulý. Pro přehledné shrnutí hlavních pramenů k různým staroegyptským kosmogonickým tradicím viz James P. Allen, Genesis in Egypt: The Philosophy of Ancient Egyptian Creation Accounts, New Haven: Yale Egyptological Seminar 1988. 
Berlínský gnostický kodex [BG] 8502; Papyrus Oxyrhynchus [P.Oxy.] 1081). ${ }^{16}$ Parrott také zdůraznil gnostickou koncepci nejvyššího „Skrytého boha“" (řec. kalyptos), jenž se objevuje celkem ve třech traktátech (Tři Setovy stély [NHC VII,5], Zostrianos [NHC VIII,1] a Allogenés [NHC XI,3]) a má přímou paralelu ve jménu významného staroegyptského boha Amona, který v překladu taktéž znamená „Skrytý“.

P. Hofrichter se domnívá, že vztažením se ke specifickým prvkům staroegyptské mytologie je možné porozumět křestanské trojiční koncepci Ježíšovy osoby coby boha, krále a člověka komplexněji, než kdybychom se pouze odkazovali na novoplatonskou antropologii. ${ }^{17}$

M. Krause poukazuje na synkretistický charakter staroegyptského náboženského myšlení, jenž se podle něj promítá i do synkretického způsobu uvažování gnostických skupin. ${ }^{18}$ Ještě důležitější pozorování ve vztahu k našemu tématu se však týká důrazu, jejž staroegyptské náboženství kladlo na kultickou praxi. Podle Krauseho tak došlo v některých gnostických skupinách (jak je vidět např́iklad ze spisů Pistis Sofia a Kniha Jeú) k formulaci takové koncepce spásy, které je možné docílit nejen poznáním, ale zejména správně propracovanou rituální praxí. ${ }^{19}$

\subsection{Podobnosti dílčích motivů}

L. Kákosy ${ }^{20}$ identifikoval jako potenciálně staroegyptské např́íklad následující motivy ve spise Pistis Sofia (Pis.Sof.): cesta duše do zásvětí skrze nejrůznější brány hlídané božskými bytostmi (Pis.Sof. 1.11 [kniha 1, kapitola 11]); ${ }^{21}$ sluneční disk obklopený hadem a měsíc cestující po obloze

16 Contra: Tuomas Rasimus, Paradise Reconsidered in Gnostic Mythmaking: Rethinking Sethianism in Light of the Ophite Evidence, Leiden - Boston: Brill 2009, 47, který se podrobně věnuje analýze setovské gnóse a jí spř́zněných skupin. Vzory hledá zejména v knize Genesis (Gen. 1-3) a vůči Parrottově interpretaci se explicitně vymezuje.

17 Peter Hofrichter, „Gnosis und ägyptische Mythologie“, in: Manfred Görg - Günter Hölbl - Stefan Wimmer (eds.), Ägypten und der östliche Mittelmeerraum im 1. Jahrtausend v. Chr.: Akten des interdisziplinären Symposions am Institut für Ägyptologie der Universität München 25.-27. 10. 1996, Wiesbaden: Harrassowitz 2000, 101-118.

18 Martin Krause, „Christlich-gnostische Texte als Quellen für die Auseinandersetzung von Gnosis und Christentum“, in: id. (ed.), Gnosis and Gnosticism: Papers Read at the Eighth International Conference on Patristic Studies (Oxford, September $3^{\text {rd }}-8^{\text {th }} 1979$ ), Leiden: Brill 1981, 47-65.

19 Viz např. Erin Evans, The Books of Jeu and the Pistis Sophia as Handbooks to Eternity: Exploring the Gnostic Mysteries of the Ineffable, Leiden - Boston: Brill 2015, který podává i přehled předešlého bádání.

20 Lászlo Kákosy, „Gnosis und ägyptische Religion“, in: Ugo Bianchi (ed.), Le origini dello gnosticismo: Colloquio di Messina 13-18 Aprile 1966, Leiden: Brill 1967, 238247.

21 Viz též krátký text Pahor Labib, „Egyptian Survivals in the Nag Hammadi Library“, in: Robert McLachlan Wilson (ed.), Nag Hammadi and Gnosis: Papers Read at the First 
v bárce (Pis.Sof. 5.136); Amente (eg. „Západ“) coby zosobnění pekla (Pis. Sof. 3.102,111; 4.127; 6.146-148); gnostické stvoření člověka z potu a slz archontů (Pis.Sof. 1.25,26,131) coby obdoba stvoření lidstva (eg. remecu) ze slz (eg. remic) Atuma, boha stvořitele. H. Jackson hledal paralelu zpodobení Jaldabaotha se lví hlavou ve staroegyptském bohu Mahesovi. ${ }^{22}$ B. Glazer poukázal na motiv „ohnivého dechu“ v Podstatě archontů (NHC II,4: 92,15-19; 95,5-13), jenž má údajně původ v Textech rakví. ${ }^{23} \mathrm{~J}$. Quack identifikoval staroegyptský základ seznamu démonů v Tajné knize Janově (NHC II,1; III,1; IV,1; PB 8502,2). ${ }^{24}$ P. Hofrichter vytvořil jakýsi přehled obecnějších podobností, přičemž poukázal na některé motivy, které nebyly předtím takto kontextualizovány. ${ }^{25}$ Ačkoliv je v gnósi postava Seta spojována se třetím synem Adama a Evy (Gen. 4:25), podle Hofrichtera je potřeba interpretovat tuto postavu v souvislosti se staroegyptským bohem Sutechem proto, že významná část gnostických proudů je s Egyptem geograficky a historicky propojena. ${ }^{26}$ Koncepce božských triád sestávajících z Otce-Matky-Syna, které se objevují v mnoha gnostických spisech, může mít podle Hofrichtera kořeny $\mathrm{v}$ praxi, jež $\mathrm{v}$ Egyptě existovala od nejstarších fází staroegyptského náboženství a ještě více vystoupila na povrch během staletí předcházejících vzniku gnostických spisů. Stejně se vyjadřuje i o autogenetických (příp. i autoerotických) koncepcích stvořitelských božstev anebo i o častém výskytu tzv. Ogdoád a Enneád, tedy uskupení různých více méně božských bytostí či principů v rámci stvořitelského procesu, jež jsou integrální součástí staroegyptských kosmogonických a teologických koncepcí od nejstarších období.

International Congress of Coptology (Cairo, December 1976), Leiden: Brill 1978, 149-151.

22 Howard M. Jackson, The Lion Becomes Man: The Gnostic Leontomorphic Creator and the Platonic Tradition, Atlanta: Scholars Press 1985.

23 Brian Glazer, ,,The Goddess with a Fiery Breath: The Egyptian Derivation of a Gnostic Mythologoumenon“, Novum Testamentum 33, 1991, 92-94.

24 Joachim F. Quack, „Dekane und Gliedervergottung: Altägyptische Traditionen im Apokryphon Johannis“, Jahrbuch für Antike und Christentum 38, 1995, 97-122.

25 P. Hofrichter, „Gnosis und ägyptische Mythologie...".

26 Contra: Birger A. Pearson, „The Figure of Seth in Gnostic Literature“, in: Bentley Layton (ed.), The Rediscovery of Gnosticism: Proceedings of the International Conference on Gnosticism at Yale New Haven, Connecticut, March 28-31, 1978, II: Sethian Gnosticism, Leiden: Brill 1981, 472-504. Hofrichterova argumentace ovšem není př́iliš přesvědčivá. 


\section{3 Ženské postavy}

Ústředního tématu tohoto textu, tedy vztahu staroegyptských a gnostických ženských postav, si všímají například J. Helderman, ${ }^{27}$ B. Layton ${ }^{28}$ a M. Malaise, ${ }^{29}$ kteří se ovšem zaměřují výhradně na bohyni Isis.

\section{Eirénaios z Lyonu: „Vlci zahalení do rouna beránkova“}

Eirénaios popisuje kosmogonické systémy dvou gnostických skupin, tzv. barbelitů a ofitů, a to v 29. a 30. kapitole první knihy Adversus haere$s e s,{ }^{30}$ přičemž ty $\mathrm{v}$ mnoha detailech odpovídají první a druhé polovině Tajné knihy Janovy, tedy textu patřícího do takzvané setovské gnóse. Zároveň obsahují mnoho tematických překryvů s dalšími texty: $O$ puvodu světa, Podstata archontů, Požehnaný Eugnóstos, Moudrost Ježíše Krista, Protennoia ve třech tvarech (NHC XIII,1), Marsanés (NHC X,1), Nórea (NHC IX,2). Kromě toho jsou podobné koncepce shrnuty i u Órigena (Contra Celsum 6.24-38) a Epifania (Panarion 26). ${ }^{31}$

Užití Eirénaiova textu jako základu srovnání se může zdát na první pohled problematické $\mathrm{v}$ tom, že ze své pozice křestanského apologety $\mathrm{k}$ těmto tradicím přistupuje a priori polemicky. Navíc tento text neodpovídá přesně žádnému dochovanému gnostickému spisu - představuje spíše jakýsi amalgám motivů, které se nacházejí napříč výše zmíněnými texty. Nicméně právě v tomto je Eirénaiův text pro účely této studie praktický, nebot ho můžeme chápat jako velice užitečnou zkratku. ${ }^{32}$

27 Jan Helderman, „Isis as planê in the Gospel of Truth“, in: Martin Krause (ed.), Gnosis and Gnosticism: Papers Read at the Eighth International Conference on Patristic Studies (Oxford, September $3^{\text {rd }}-8^{\text {th }}$ 1979), Leiden: Brill 1981, 26-46.

28 Bentley Layton, ,The Riddle of the Thunder (NHC VI,2): The Function of Paradox in a Gnostic Text from Nag Hammadi“, in: Charles W. Hedrick - Robert Hodgson, Jr. (eds.), Nag Hammadi, Gnosticism, and Early Christianity, Peabody, MA: Hendrickson 1986, 37-54.

29 Michel Malaise, „Isisme et Gnosticisme“, in: Julien Ries (ed.), Gnosticisme et monde hellenistique: Actes du colloque de Louvain-la-Neuve (11-14 Mars 1980), Louvain-laNeuve: Peeters 1982, 47-60.

30 Standardní edicí zůstává Adelin Rousseau - Louis Doutreleau, Irénée de Lyon: Contre les hérésies I, Paris: Éditions du CERF 1979. V češtině viz shrnutí v Jaroslav Matoušek, Gnose, čili tajné učení náboženské posledních století pohanských a prvních křestanských, Praha: Herrmann a synové 1994, 153-157. Pro český překlad viz Jan N. F. Desolda, Svatého otce Irenea patero kněh proti kacířstvím: S některými dodatky, Praha: Dědictví sv. Prokopa 1876.

31 T. Rasimus, Paradise Reconsidered..., viz zejm. shrnující diagram na s. 62.

32 Podobně argumentují i Alastair Logan, Gnostic Truth and Christian Heresy: Origins and Development of a Classic Gnostic Myth, Edinburgh: T and T Clark 1996; David Brakke, The Gnostics: Myth, Ritual, and Diversity in Early Christianity, Cambridge: 
Podle Eirénaia (AH 1.30.1) byl na počátku Bythus (Hlubina), prvotní světlo, jež bylo Praotcem, Prvním člověkem. Z něj vzešla Ennoia (Myšlenka), která dala povstat jeho synu, Druhému člověku. Následuje Duch svatý, který je ženského pohlaví, též nazývaný První žena, Matka všeho živoucího. ${ }^{33}$ Kromě toho byly stvořeny i čtyři principy: voda, temnota, propast a chaos. První a Druhý člověk s První ženou zplodili Krista, třetí mužskou emanaci (AH 1.30.2). Kristus se společně s První ženou následně vznesli do věčného Eónu, kde sídlí První a Druhý člověk, a tito čtyři společně vytvořili pravou a svatou církev. Kristus byl stvořen na pravou stranu a prírozeně tendoval $\mathrm{k}$ oblastem vyšším, zatímco na levou stranu překypěla část světla do chaotické hmoty (AH 1.30.3) a vznikla androgynní bytost zvaná Sinistra (Levá), respektive Prunicus ${ }^{34}$ nebo Sofia. Ta rozpohybovala spodní statické vody, do nichž sestoupila a z nichž vzniklo její tělo. Vzhledem k přítomnosti božského světla ve svém těle se Sofia chtěla vrátit k Matce, ale nemohla, nebot tíha těla byla př́liš velká. Utvořila tedy alespoň ze svého těla oblohu (AH 1.30.4-5). Kontaktem s hmotou (vodami) zplodila Sofia syna, jenž měl „,nádech neporušitelnosti“ a jmenoval se Jaldabaoth. Ten vzápětí zplodil syna (Jao), ten měl dalšího syna (Sabaoth) až do celkového počtu sedmi členů (Adoneus, Eleoeus, Oreus, Astanfeus). Tyto bytosti společně se svou matkou tvoří dohromady Osmero (Ogdoádu) (AH 1.30.6). Stvoření následně pokračuje a vrcholí stvořením člověka (AH 1.30.7), přičemž v jeho poslední fázi Jaldabaoth pocítí vůči Adamovi závist a stvoří ženu, aby ho obral o jeho světelný paprsek, který měl od Sofie, a dostal ho tak pod svou moc. Sofia vzápětí seslala hada do ráje. Adam a Eva procitli poznáním, porušili Jaldabaothovy př́ikazy (AH 1.30.8) a byli vyhnáni z ráje.

Harvard University Press 2012; Thomas Gaston, „The Egyptian Background of Gnostic Mythology“, Numen 62/4, 2015, 389-407: 392.

33 Přehledný výklad o vnímání ,pohlavi““ Ducha svatého v závislosti na různých tradicích viz James M. Robinson, „Very Goddess and Very Man“, in: Karen L. King (ed.), Images of the Feminine in Gnosticism, Philadelphia: Fortress 1988, 113-127; Charles W. Hedrick, ,Response to ,Very Goddess and Very Man“ by James M. Robinson“, in: Karen L. King (ed.), Images of the Feminine in Gnosticism, Philadelphia: Fortress 1988, 128-135.

34 Anna Pasquier, „Prouneikos: A Colourful Expression to Designate Wisdom in Gnostic Texts“, in: Karen L. King (ed.), Images of the Feminine in Gnosticism, Philadelphia: Fortress 1988, 47-66; Marvin W. Meyer, „Response to ,Prouneikos: A Colourful Expression to Designate Wisdom in Gnostic Texts " by Anne Pasquier", in: Karen L. King (ed.), Images of the Feminine in Gnosticism, Philadelphia: Fortress 1988, 67-70. 


\section{Paralely mezi Eirénaiovým traktátem a staroegyptskou Chonsuovou kosmogonii}

Text tzv. Chonsuovy kosmogonie (ChK) má formu popisek k vyobrazením staroegyptských božstev vytesaných na vnitřních zdech obklopujících svatostánek v Chonsuově chrámu v Karnaku (lokalizovaném ve městě Vaset [eg.], resp. Théby [řec.]). ${ }^{35}$ Jak název napovídá, do centra všech kosmogonických událostí je zde kladen bůh Chonsu, asociovaný s měsícem. $\mathrm{V}$ průběhu skladby je ovšem zcela ve staroegyptském synkretistickém duchu ztotožněn se všemi klíčovými mužskými i ženskými postavami staroegyptského panteonu. ${ }^{36}$ Vznik skladby je datován do období mezi Ptolemaiem VIII a Augustem (170 př. Kr. až 14 po Kr.). ${ }^{37}$

V následujících odstavcích si představíme ústřední motivy, jež je možné vztáhnout k Eirénaiově shrnutí. Ve své analýze přitom navazuji a zároveň polemizuji se závěry T. Gastona, který oba texty srovnal vůbec poprvé ve své studii z roku 2015. ${ }^{38}$

Nejrelevantnější z Gastonových pozorování je srovnání gnostické Hlubiny (Bythus), z níž povstane První člověk (AH 1.30.1), se staroegyptským Nunem (Pravodstvem) ${ }^{39}$ coby chaotickým vodním prostředím, $\mathrm{z}$ něhož povstane stvořitel Amon-Re (ChK 34.44). Čtveřice principů (voda, temnota, propast a chaos, AH 1.30.4-5), které byly stvořeny v raných fázích gnostického stvořitelského procesu, svou strukturou zcela odpovídá oblastem, které jsou v staroegyptské ChK zastoupeny tzv. hermopolskou Ogdoádou (Nun a Naunet [Pravodstvo]; Kek a Keket [Temnota]; Nau a Nauet [Propast]; Heh a Hehet [Nekonečná rozlehlost], ChK 35.15). Vznik sedmera Džájsu (personifikované výroky primordiálního božstva), kteří jsou stvořeni skrze působení Hathory, respektive Esety (ChK 36.15-22, 24), je zase velice podobné koncepci stvoření nebeského a archontského Sedmera a sedmera nebes (AH 1.30.8-9, 12), která stvořitele obklopují.

Gastonova interpretace má ovšem zcela zásadní problém v tom, že se snaží otrocky nalézt zrcadlový odraz generačních vztahů v Eirénaiově shrnutí a ve staroegyptském kosmogonickém mýtu. V Gastonově převy-

35 Eugene Cruz-Uribe, „The Khonsu Cosmogony“, Journal of the American Research Center in Egypt 31, 1994, 169-189.

36 Tato strategie měla zřejmě za cíl umístit dané božstvo do středu všech klíčových kosmických událostí, posílit tak jeho pozici a potažmo i pozici kněží, kteří jeho kult spravovali, viz např. ibid., 189.

37 Ibid., 184.

38 T. Gaston, ,The Egyptian Background...“.

39 Nun je zosobněním prvotních vod, tedy všeho nerozlišeného - včetně principu mužského a ženského. Z tohoto hlediska je vnímán v určitém androgynním aspektu. Často je navíc zobrazován jako had, který se obtáčí kolem boha stvořitele v „,nekonečných“ smyčkách. 
právění to sice funguje a paralely skutečně nalézá, ovšem za cenu nepřijatelných zjednodušení. Jakmile totiž konfrontujeme jeho koncepci s původním textem ChK, emanační schéma fungovat přestane. Božských postav je v ChK mnohem více, než kolik jich zmiňuje Gaston, a jeho výběr je tak zcela podřízený závěru, $\mathrm{k}$ němuž chce dospět. Oba texty přitom obsahují paralely, jež Gaston zcela pomíjí a které považuji za důležitější.

Odkazem na staroegyptské vzory se například velice vhodně vysvětluje vztah mezi prvními třemi mužskými a doprovodnými ženskými emanacemi i androgynní prvky Ducha svatého. Podle gnostických textů První a Druhý muž souloží s prvotním ženským principem, a dávají tak povstat Třetímu muži. Všichni společně ovšem tvoří dohromady celek (svatou a pravou církev, AH 1.30.1). Kromě toho, že je zde specifickým způsobem užita sexuální symbolika, což je standardní staroegyptský diskurz v podobných kontextech, ${ }^{40}$ řeši se v rámci tohoto obrazu interakce mužského a ženského principu a hlavně princip autogeneze: stvořitelská bytost plodí sama skrze svou emanaci prvek, který ji následně doplňuje a dotváří její celistvost. V ChK se velice obdobně setkáváme s motivem stvoření sama ze sebe, který je konceptualizovaný skrze na první pohled komplikovanou strukturu překrývání stvořitele a stvoření (stvořitel tvoří stvořené, které dává opět povstat stvořiteli). ${ }^{41}$ Tento paradoxní vztah, jejž je vlastně nemožné postihnout sekvenčně, nebot' se v okamžiku stvoření děje jaksi naráz, je vyjádřen skrze božské personifikace (mužského i ženského pohlaví), které jsou následně dané do vzájemných paralelních vztahů stvořenosti a identity. Ačkoliv tedy tyto bytosti tvoři ,generace“, celá staroegyptská teologická koncepce pracuje s velice sofistikovaným systémem odkazů, které, zjednodušeně řečeno, vedou k celkové synkrezi jednotlivých postav do jakéhosi božského demiurgického ,pra-prvotního spečen-

40 Stvořitelský akt je například v rámci tzv. héliopolské kosmogonie popisován jako autoerotický akt boha stvořitele. Jeho pravá ruka dokonce získá svébytnost v postavě bohyně Jusas.

41 Vzhledem $\mathrm{k}$ důležitosti tohoto motivu $\mathrm{v}$ gnostických systémech bude dobré si tuto stvořitelskou dynamiku ve staroegyptském textu shrnout: Amon (,Skrytý“) vzal na sebe podobu Prvního hada a stvořil nebe skrze svou touhu (ChK 35.7), respektive ejakuloval do Nunu, prvotních vod (35.12). Partnerkou v tomto aktu mu byla bohyně Hathor (35.18-19), která je ztotožněna se semenem[-vejcem] (35.31), jež z tohoto aktu vzešlo (35.8, 11-13). Z vejce se vylíhnul Druhý had (35.8), Irta („Stvořitel země“). Druhý had, zdá se, zastupuje druhou generaci bohů, která je v tomto př́ipadě taktéž ztotožněna s Ogdoádou $(35.13,19)$. Amon-stvořitel druhou generaci bohů / Druhého hada / Ogdoádu / vody Nunu spolknul (ve významu „otěhotněl jimi“) (35.14) a v podobě Chonsua se odebral do Karnaku, kde ke stvoření samotnému skrze Ogdoádu došlo (35.15). Ačkoliv stvořitel stvořil Ogdoádu, v určitém smyslu Osmero stvořilo stvořitele - plulo na Ohnivý ostrov, kde dalo povstat „Prvotnímu prastarému z Mehetverety (,Velké záplavy‘)“ (35.22-23). Ogdoáda přitom zároveň dala povstat Reovi (slunci) (35.28), jenž byl ovšem již na počátku textu identifikován právě s Amonem. 
ce“. Tím můžeme vysvětlit silné androgynní, respektive gynandrické aspekty, které jsou u těchto postav zjevné. Ty jsou přitom velice silné i v gnostických pramenech. K tomuto argumentu se ještě vrátíme v části popisující kulty tzv. Velkých bohyň.

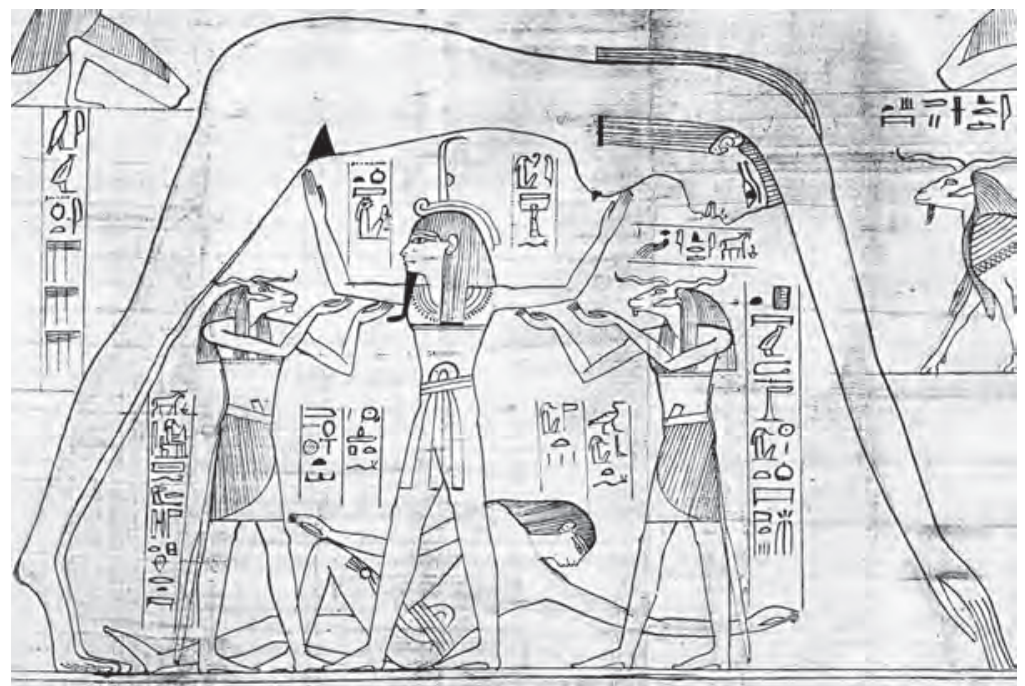

Obr. 1. Staroegyptská bohyně Nut tvořící nebeskou klenbu, podpíraná bohem vzduchu Šuem. ${ }^{42}$

Zajímavý je také moment, kdy v AH 1.30.3 dochází k oddělení mužské a ženské části androgyna a k vytvoření nebeské oblohy, hranice, z těla Sofie (viz výše). V korpusu původních gnostických textů je tato část narativu zachycena např́klad ve Valentinovském výkladu (NHC XI,2: 34-35). Ačkoliv je to velice enigmatická pasáž, zjevně se jedná o akt rozdělení Sofie a Krista ve velice podobném duchu jako v Eirénaiově shrnutí. Okamžitě ovšem upoutá svou doslovnou podobností se staroegyptským motivem bohyně Nut. Ta je součástí tzv. héliopolské Enneády, v níž je partnerkou boha Geba, což je druhá božská generace od vydělení se z prvotní hlubiny, pravodstva Nun. Aby mohlo vzniknout světlo čili zrodit se bůh Re (a tedy i čas), bůh vzduchu Šu (božstvo první generace) od sebe oddělí bohyni Nutu (nebeskou klenbu) a Geba (zemi), kteří spolu do té doby existovali v úzkém spojení (viz obr. 1). Ačkoliv tato představa expli-

42 Z Knihy mrtvých, vznik cca 950 př. Kr., ve sbírce Britského muzea, EA10554,87. Převzato z: https://commons.wikimedia.org/wiki/File:Geb,_Nut,_Shu.jpg. 
citně v ChK př́itomná není, s koncepcí héliopolské kosmogonie ChK pracuje a $\mathrm{v}$ rámci staroegyptského prostředí byl tento obraz notoricky známý. ChK zkrátka tvoří velikou kosmogonickou tapisérii, jejíž některá vlákna byla ve 2 . století př. Kr. stará již více než tisíc let. ${ }^{43}$

Posledním klíčovým motivem, který nás zároveň přirozeně přenáší $\mathrm{k}$ hlavnímu bodu této studie, je ústřední role ženských postav v celém procesu stvoření. Má pracovní teze je taková, že i tento motiv (přítomný v nejrůznějších gnostických tradicích) byl pravděpodobně silně inspirován právě původní staroegyptskou náboženskou tradicí. Podívejme se nejprve na situaci ženských postav / božských bytostí v různých gnostických směrech.

\section{Hlas (Paní) hromu:}

\section{Klíčová role ženských postav v gnostických tradicích}

Důvody k zaměření se na ženské postavy mám v zásadě dva. Zaprvé, ve srovnání s texty křestanskými, židovskými, případně novoplatónskými, gnostické texty skutečně oplývají množstvím výrazných ženských postav anebo principů, které jsou systémově zcela konstitutivní at už v pozitivním, či negativním smyslu slova, ${ }^{44}$ respektive mnohé $\mathrm{z}$ těchto textů užívají genderové kategorie (tj. nejen pouze „,̌̌ena“, ale i „muž“, případně různé kombinace obojího) jako klíčový koncepční prvek, a to mnohdy velice originálním způsobem. ${ }^{45}$ Zadruhé, pro samotnou staroegyptskou náboženskou tradici byly ženské postavy zásadní (viz následující kapitola) a v řecko-římské době tento trend ještě výrazným způsobem posílil.

Nutno podotknout, že důležitosti ženských postav/principů v gnósi se za posledních padesát až šedesát let věnovalo mnoho autorů a autorek. ${ }^{46}$ V následujících odstavcích se proto pokusím poskytnout reprezentativní

43 Autoritativnost textu ChK měla být posílena i tím, že byl zapsaný v archaizující formě egyptštiny, v tzv. střední egyptštině s některými pozdně-egyptskými gramatickými prvky, nicméně v čistě pozdně-egyptské ortografii. Viz Richard A. Parker - Leonard H. Lesko, „The Khonsu Cosmogony“, in: John Baines - T. G. H. James - Anthony Leahy - A. F. Shore (eds.), Pyramid Studies and Other Essays Presented to I. E. S. Edwards, London: Egypt Exploration Society 1988, 168-175.

44 Frederick Wisse, „Flee Femininity: Antifemininity in Gnostic Texts and Question of Social Milieu“, in: Karen L. King (ed.), Images of the Feminine in Gnosticism, Philadelphia: Fortress 1988, 297-307.

45 Viz např. přehledovou studii Anne M. McGuire, „Women, Gender, and Gnosis in Gnostic Texts and Traditions“, in: Ross Shepard Kraemer - Mary Rose D’Angelo (eds.), Women and Christian Origins, New York: Oxford University Press 1999, 257 299.

46 Pro velice nápomocný, byt mírně zastaralý, status quaestionis, viz např. ibid. Za pozornost stojí i výše opakovaně zmiňovaný sborník Karen L. King (ed.), Images of the Feminine in Gnosticism, Philadelphia: Fortress 1988. 
přehled, jehož smyslem bude představit základní fenomenologii tohoto motivu. Ženské postavy, které se v gnostických textech vyskytují, rozdělila A. McGuire do tří kategorií:

... (1) božské postavy jako například Barbeló/Protennoia, Sofia ${ }^{47}$ a její dcera Zoé ad.; (2) mytické ženy prapůvodního času jako například Eva a její dcera Nórea; (3) legendární ženy méně vzdálených dob jako například Máří Magdaléna, Salome, Marta. Texty se dále explicitně vztahují ke kategoriím ,ženskosti“ a „mužskosti“ a užívají celou škálu jemnějších, avšak genderově odstíněných termínů, pojmů a obrazů příbuznosti, způsobů pohlavního rozmnožování, zrození, svatby, prostituce a znásilnění. ${ }^{48}$

Ve svém příspěvku se soustředím na ty aspekty, které popisují ženy jako integrální a neodmyslitelnou součást kosmogonického/emanačního procesu a zároveň zdůrazňují ambivalentní polohu, do které jsou v těchto textech stavěny. Dále se zaměřím na unikátní text, aretalogii či zjevení podané z perspektivy ženského principu s názvem (Paní) hromu: Dokonalá mysl [Hrom] (NHC VI,2). ${ }^{49}$ Jak následně ukáži, tento text je v mnoha ohledech výjimečný a díky tomu je z celého gnostického korpusu nejjednodušší na něm ukázat případné staroegyptské vlivy, a to zejména skrze analýzu charakteru hlavní ženské postavy.

Spis Hrom sestává ze série hymnických výpovědí, které mají formu sebe-zjevení. Dozvídáme se, že (Paní) hromu přichází na svět z pověření „vyšší moci“ $(13,2)$, zároveň to ovšem vypadá, že byla do světa vyhnána (19,28-30). Má tak paradoxní vztah k těm, kteří mají upřímnou touhu ji poznat - je jim nablízku i vzdálená $(18,29-19,3)$. Pokud se posluchači odhodlají přijmout ji ve všech jejích paradoxech a vymaní se z moci hříchu, mohou za ní ,„prchnout“" vzhůru (21,20-28). Mnoho jejích charakteristik je uvozeno frází „Já jsem...“, po kterých (Paní) hromu (Brontê) specifikuje své vlastnosti, přičemž každá informace je zároveň doprovázená zcela opačnou, respektive paradoxní výpovědí:

47 Viz též Pheme Perkins, „Sophia as Goddess in the Nag Hammadi Codices“, in: Karen L. King (ed.), Images of the Feminine in Gnosticism, Philadelphia: Fortress 1988, 96112.

48 A. M. McGuire, „Women, Gender, and Gnosis...", 267.

49 Faksimile: James M. Robinson (ed.), The Facsimile Edition of the Nag Hammadi Codices: Codex VI, Leiden: E. J. Brill 1972, pl. 17-25. Překlady: George W. MacRae, „The Thunder: Perfect Mind“, in: James M. Robinson (ed.), The Nag Hammadi Library in English: Third, Completely Revised Edition, San Francisco: Harper and Row 1990, 295-303. Pro český překlad a úvodní studii viz Z. Vítková, „Hrom...“. Pro podrobnou analýzu struktury viz Tilde B. Halvgaard, Linguistic Manifestations in the Trimorphic Protennoia and the Thunder: Perfect Mind Analysed against the Background of Platonic and Stoic Dialectics, Leiden: Brill 2016, 98-165. 
Pamatujte! Nezapomínejte na mne! / Vždyt já jsem první i poslední. / Já jsem ta, která je uctívána, i ta, jíž pohrdají. / Já jsem prodejná i ctihodná. / Já jsem manželka i panna. / Já jsem <matka $>$ i dcera. ${ }^{50}(13,14-20)$

Ohledně svého původu popisuje (Paní) hromu komplikovaný vztah vzájemné stvořenosti se svým stvořitelem. Jak si ještě podrobněji ukážeme níže, toto ji zásadním způsobem spojuje i s pozicí ženských božstev v tradici staroegyptské:

Já jsem útěchou svých porodních bolestí. / Já jsem nevěsta i ženich, / a je to můj muž, který mne zplodil. / Já jsem matkou svého otce a sestrou svého muže, / a on je můj potomek. / Já jsem služebnicí toho, / který mne připravil. / Já jsem paní svého potomka, / avšak je to on, kdo mne [zplodil] / na počátku času, ve [dnu] zrození, / a on je mým potomkem [v] čase / a moje síla je z něj. / Já jsem oporou moci v jeho mládí / [a] on je holí mého stář́i. ${ }^{51}(13,28-14,7)$

Někteří komentátoři podotýkají, že Hrom je z formálního i obsahového hlediska v mnoha ohledech v rámci korpusu gnostických textů výjimečný, a snaží se jej vyčlenit:: ${ }^{52}$ „Neobsahuje žádné výslovně křestanské, židovské anebo gnostické aluze a nepředpokládá žádný konkrétní gnostický mýtus. “53 D. M. Parrott proto hledá možnou inspiraci např́íklad ve stoickém pneumatu, tedy principu, který stojí v základech stvořeného světa a do něhož se vše navrátí. Pneuma zároveň ve své kapacitě rozumu vede ty, kteří hledají pravou cestu (podobně i [Paní] hromu v Hrom 20,26-27; 21,20-32). ${ }^{54}$ Nicméně, jak sám podotýká, je to pouze jistá znouzectnost. Dospívá proto k závěru, že „,[s]vou koncepcí imanence božského ve všech aspektech stvořeného světa se ovšem [Hrom] vymyká [i kategorii] ,gnostický““.55 Podle mého názoru ovšem Hrom, přes všechny své zvláštnosti, obsahuje zcela „gnostické“ prvky: imanenci božského v tomto světě a ústř̌ední roli ženského božstva, jež ze své prostředkující pozice pomáhá člověku v jeho snaze oprostit se od vlády archontů. Velice podobně je popisována i (Paní) hromu. V tomto smyslu má Hrom obsahově nejblíže $\mathrm{k}$ textům řazeným $\mathrm{k}$ tzv. setovské gnózi, v nichž se navíc vyskytují i podobně uvozené věty „Já jsem..." (Protennoia ve třech tvarech [NHC

50 Překl. Z. Vítková, „Hrom...“, 50.

51 Překl. ibid., 51.

52 Viz např. G. W. MacRae, „The Thunder...“, 295.

53 Ibid., 296.

54 Douglas M. Parrott, editorský komentář v G. W. MacRae, ,,The Thunder...“, 296. Dirk Baltzly, „Stoicism“ [online], <https://plato.stanford.edu/archives/spr2008/entries/ stoicism/>, 7. 2. 2008 [3.6. 2019]; tato pozice je podrobněji rozpracovaná v T. B. Halvgaard, Linguistic Manifestations...

55 D. M. Parrott v G. W. MacRae, „The Thunder...“, 296. Parrott zcela jistě míní skutečnost, že zde není patrný dualizmus, který je podle mnohých autorů definujícím prvkem gnosticismu. 
XIII,1] a Tajná kniha Janova [NHC II,1: 30,11-31,25]). ${ }^{56}$ Jako další možná paralela jsou zmiňovány starozákonní a pseudoepigrafní sapienciální knihy, v nichž vystupuje a promlouvá Boží Moudrost (Sofia). ${ }^{57}$ Potenciálně nejbližším žánrem by ovšem mohly být tzv. Isidiny aretalogie - druh posvátné biografie, jež v první osobě (za užití uvození „Já...") a hymnickou formou vyjmenovává vlastnosti Isidy coby světovládné bohyně, přičemž se badatelé víceméně shodují, že texty organicky vycházejí ze staroegyptského prostředí. $^{58} \mathrm{Ve}$ všech třech zmiňovaných paralelách ovšem spočívá hlavní problém v absenci oněch paradoxních výroků, které jsou pro Hrom zcela klíčové. ${ }^{59}$

Ačkoliv badatelé předpokládají, že Hrom je koptským překladem řeckého originálu, podobně jako ostatní rukopisy naghammádského korpusu, kultivovaný jazyk, kterým je Hrom sepsaný, vede například Plische k domněnce, že by se mohlo jednat o zcela původní egyptský text (ve smyslu geografickém). ${ }^{60}$ Domnívám se proto, že asociace s Isidinými aretalogie$m i$, která text úzce spojuje s Egyptem skrze postavu bohyně Isis, mírí správným směrem. Toto spojení s Egyptem je přitom přímočaře vyjádřeno (při zachování paradoxního tónu celé skladby) i v textu samotném:

Proč jste mne tedy nenáviděli, Řekové? / Že jsem barbarka mezi barbary? / Vždyt já jsem moudrost Řeků / a poznání barbarů. / Já jsem odsouzení Řeků i barbarů. / Já jsem ta, jejíchž podob je v Egyptě mnoho, / a ta, která mezi barbary žádnou podobu nemá. ${ }^{61}(16,2-10)$

56 Uwe-Karsten Plisch, „Die Brontê - Vollkommener Verstand (NHC VI,2)“, in: HansMartin Schenke et al. (ed.), Nag Hammadi Deutsch II: NHC V,2-XIII,1, BG 1 und 4, Berlin - New York: Walter de Gruyter 2003, 455-466. Podobné stanovisko zastává i Z. Vítková (e-mailová komunikace 22. 6. 2019).

57 Z. Vítková, „Hrom...“, 41, pozn. 7; 44, pozn. 31; George W. MacRae, „The Jewish Background of the Gnostic Sophia Myth,“ Novum Testamentum 12/2, 1970, 86-101.

58 Jan Bergman, Ich bin Isis: Studien zum memphitischen Hintergrund der griechischen Isisaretalogien, Uppsala: Almqvist and Wiksell 1968; Gilles Quispel, „Jewish Gnosis and Mandean Gnosticism: Some Reflections on the Writing Brontè“, in: Jacques-É. Ménard (ed.), Les textes de Nag Hammadi (Colloque du Centre d'histoire des religions, Strasbourg, 23-25 Octobre 1974), Leiden: Brill 1975, 82-122: 88; George W. MacRae, „Discourses of the Gnostic Revealer“, in: Geo Widengren - David Hellholm (eds.), Proceedings of the International Colloquium on Gnosticism, Stockholm August 20-25, 1973, Leiden: Brill 1977, 111-122: 116; B. Layton, „The Riddle of the Thunder...", 44.

59 J. J. Buckley navrhuje ještě paralely v mandejských gnostických textech (Jorunn Jacobsen Buckley, „Two Female Gnostic Revealers“, History of Religions 19/3, 1980, 259-269: 259; viz též Z. Vítková, „Hrom...“, 47-48.)

60 U.-K. Plisch, „Die Brontê...“, 456 f.

61 Překl. Z. Vítková, „Hrom...“, 53. Zuzana Vítková (e-mailová komunikace 22. 6. 2019) ve své interpretaci zdůrazňuje spíše absolutní nárok (Paní) hromu na spasitelskou roli ve vztahu ke všem lidem, at už ji znají (Řekové v Egyptě), anebo i k těm, kteří ji ještě neznají (barbaři mimo Egypt). 
Zároveň chci ovšem hájit myšlenku, že hledání paralel v Isidiných aretalogiích uvízlo napůl cesty. Tyto skladby totiž nevznikly ve vakuu, ale navazovaly na intelektuálně velice bohaté teologické texty, které byly komponovány kněžími a $\mathrm{v}$ hieroglyfickém písmu zapisovány na stěny chrámů dedikovaných významným ženským bohyním (Eset, Neit, Hathor atd.) a rozmístěných po celém Egyptě. Kulty těchto bohyní přitom doznaly zejména $\mathrm{v}$ řecko-římském období značného rozvoje. Podobně jako tomu bylo i v př́padě Chonsuovy kosmogonie, byly tyto jednotlivé bohyně v rámci daného chrámu nejenom popisovány jako svrchované vládkyně a stvořitelky (často v androgynních aspektech), ale skrze sofistikovaná synkretická a emanační schémata byly identifikovány s ostatními klíčovými (ženskými) postavami a principy staroegyptského panteonu.

\section{Klíčová role ženských postav ve staroegyptské tradici}

Ženské postavy měly $\mathrm{v}$ rámci staroegyptské tradice naprosto výsadní postavení od nejstarších dob. ${ }^{62}$ Ačkoliv ústředním tématem královské ideologie byl Usirův příběh o zavražděném a následně vzkř̌išeném bohu, jehož vlády se následně ujímá jeho syn Hor coby legitimní nástupce, celý model by nemohl fungovat bez přispění bohyně Eset. Byla to právě Eset, kdo shromáždil údy Usirova těla poté, co je Sutech rozesel po celém Egyptě; byla to Eset, která skrze svou kouzelnou moc počala s mrtvým Usirem Hora; byla to Eset, která chránila Hora po dobu jeho dětství před Sutechovými nástrahami; byla to Eset, kdo zásadním zpưsobem vstupoval do následnického sporu mezi Sutechem a Horem a bez jejíž intervence by celá situace opakovaně zamrzla $v$ neřešitelném patu. Tento příklad jsem přitom použil proto, že je nejznámější. Týká se ovšem i mnoha dalších ženských postav bez ohledu na to, zda jsou $\mathrm{v}$ pramenech označeny jako bohyně, či nikoliv. Ženy měly zkrátka v rámci mytologického systému starého Egypta poměrně výsadní, i když velice dvouznačnou pozici. Byly to mocné bezmocné. ${ }^{63}$

Pokud bychom tedy měli nějak generalizovat typ moci, který ve staroegyptské literatuře náležel výlučně ženským postavám, mohli bychom jej nazvat ambivalentní mocí prostřednic. Mediátorky v rámci jasně polarizovaného kosmu stojí někde „mezi“ jednotlivými stranami, mezi nimiž prostř̌edkují. K jednotlivým skupinám mají blízký vztah, ale jejich vnitřní struktura je tolik nesvazuje. To umožňuje mediátorkám, často za užití ně-

62 Martin Pehal, Interpreting Ancient Egyptian Narratives: A Structural Analysis of the Tale of Two Brothers, the Anat Myth, the Osirian Cycle and the Astarte Papyrus, Bruxelles: EME 2014, 218-220.

63 Martin Pehal, „Mocné bezmocné: Ženy ve společnosti a mytologii starověkého Egypta“, Pražské egyptologické studie 8, 2011, 49-54. 
jakého „triku“, vyřešit situaci, která je z hlediska mužských zástupců mocenských kategorií neřešitelná. A protože činy ženských postav mívají zásadní dopad na kosmické události, je jejich jednání v textech vnímáno jako silně ambivalentní a paradoxní - přesně v tom smyslu, v jakém se s ním setkáváme v gnostické promluvě (Paní) hromu. ${ }^{64}$

Tento ambivalentní aspekt ženských postav můžeme ilustrovat na postavě oka boha stvořitele (Re, Atum aj.). V egyptštině se tato postava nazývá iret, což je podstatné jméno ženského rodu. Oko je vhodný symbol pro naši analýzu z toho důvodu, že téměř všechny staroegyptské bohyně s ním byly v určitém kontextu ztotožněny (nejčastěji ovšem Hathor a Sachmet). Mytologie, která je s tímto symbolem spojována, je velice komplexní. To dokazuje i skutečnost, že v egyptologické literatuře zatím neexistuje žádná práce, která by se tématem holisticky zabývala. ${ }^{65}$ Oko reprezentuje destruktivní, nezvladatelnou sílu, která stvořitele/panovníka ochraňuje proti jeho nepřátelům, jak je velice barvitě vykresleno např́klad v Knize nebeské krávy. ${ }^{66}$ Tento text vypráví o vzpouře lidí proti jejich vládci, Reovi. Napjatou situaci vyřeší Reovo oko, které sestoupí na zem a v podobě bohyně Sachmet začne vzpurné poddané pobíjet. Reovi se zbytku lidstva zželí a pomocí důmyslného plánu se mu podaří bohyni opít pivem (čímž se lví Sachmet transformuje do klidné, kočičí podoby bohyně Bastet). Ta následně zapomene na svůj vražedný záměr a lidstvo je zachráněno.

Kromě této ambivalence v sobě mytologie asociovaná s okem obsahuje i silný motiv prostředkování spojovaného zejména s okamžikem stvoření kosmu. V Bremner-Rhindově papyru (pBM 10188) ${ }^{67}$ nalezneme monolog boha stvořitele, Pána veškerenstva $(26,22-27,4)$. V jeho rámci Bůh Atum

64 Ke stejnému závěru dospívá opakovaně i Z. Vítková ve svém komentáři k překladu Hromu (viz Z. Vítková, „Hrom...").

65 Pro výchozí bádání je dobré začít s Eberhard Otto, „Augensagen“, in: Wolfgang Helck - Eberhard Otto - Wolfhart Westendorf (eds.), Lexikon der Ägyptologie I, Wiesbaden: Harrasowitz 1975, cols. 562-567. Stručné, ale přehledné shrnutí problematiky poskytuje také Susanne Bickel, La cosmogonie égyptienne avant le Nouvel Empire, Fribourg: Edition universitaires 1994, 91-100.

66 Základní dílo k tomuto tématu je Erik Hornung, Der ägyptische Mythos von der Himmelskuh: Eine Ätiologie des Unvollkommenen, Freiburg - Göttingen: Vandenhoeck und Ruprecht 1982. Velice zajímavé postřehy má i Anthony Spalinger, „The Destruction of Mankind: A Transitional Literary Text“", Studien zur altägyptischen Kultur 28, 2000, 257-282.

67 Ačkoliv text papyru pochází z poměrně pozdní doby (30. dynastie, cca 400 př. Kr.), motivy, se kterými se zde setkáváme, se ve fragmentárnější podobě vyskytují v textech starších. Pasáž, která nás bude zajímat, pochází z Knihy vítězství nad Apopem (26,2227,3). Překlad je podle hieroglyfického přepisu hieratického (kurzivního) textu v Raymond O. Faulkner, The Papyrus Bremner-Rhind (British Museum No. 10188), Bruxelles: Fondation égyptologique reine Élisabeth 1933, 60-61. 
popisuje, kterak skrze autoerotický akt stvořil mužsko-ženský princip v podobě bohyně Tefnut a boha Šua:

Já jsem ten, který povstal ${ }^{68}$ coby Cheprer („,Vznikající“). Když jsem povstal, vzniklo stvoření. Všechno stvoření vzniklo poté, co jsem já povstal ... Počal jsem se svou rukou, spojil jsem se se svou rukou, svými vlastními ústy jsem plivnul. Vykýchnul jsem [eg. ǐš $\check{s}$ - pozn. autora] Šua, vyplivnul jsem [eg. tef - pozn. autora] Tefnutu. Byl to můj otec, Praoceán Nun, který je vychoval. Pak se mi vzdálili a mé oko je následovalo. Poté, co jsem se stal jedním bohem, byli ve mně bohové tři. ${ }^{69}(26,22-23)$

To, co text zdůrazňuje, je absolutní jednota prvotního božstva. Předtím, než vznikla mnohost a celý stvořený kosmos, Pán veškerenstva tvořil sám v sobě dokonalý celek. Následně skrze autoerotický akt vznikla další stvoření, tedy mnohost. Bůh Šu a bohyně Tefnut představují v rámci héliopolské kosmogonické tradice první bytosti, které z pohlavně nediferencovaného prvotního božstva vznikly - nyní již ovšem jako polarizovaný pár sjednocující mužský a ženský princip. Podle textu se zdá, že jediným úkolem oka je dovést tato dvě božstva, která se od Pána veškerenstva „vzdálila“, zpět ke stvořiteli. Vzhledem k tomu, že Pán veškerenstva byl na počátku zcela jednotný, jakákoliv mnohost, které dal v sobě vzniknout, znamená oddělení, a tedy oddálení částí kdysi jednolitého celku. Dříve, než bude moci Pán veškerenstva dát stvořenému světu $v$ jeho mnohosti řád, je potřeba tyto jednotlivé části shromáždit a uspořádat. Text proto pokračuje:

Když jsem se projevil v tomto světě, Šu a Tefnut se radovali v Pravodstvu, v němž se nacházeli. Pak mi přinesli mé oko a já jsem spojil své údy. (27,2)

Oku se podařil úkol, kvůli kterému bylo vysláno. Prvotní božský pár nalezlo a při svém návratu bylo navráceno svému majiteli, Pánu veškerenstva. V této pasáži Pán veškerenstva vysloveně nazývá jednotlivá božstva „svými částmi“", které následně spojuje.

Oko zde tedy hraje roli prostřednice, bez které nemůže stvoření pokračovat. Oko je zde zhmotněním vztahu, který musí být nejprve mezi jednotlivými částmi kdysi jednotné božské entity vytvořen (vztah je nejprve jednosměrný - od stvořitele ke stvořenému, s návratem oka se stává vzájemným). Pán veškerenstva sice disponuje mužskou sexuální plodivou silou, jejíž výron v podobě ejakulace/vyplivnutí/vykýchnutí vytváří pluralitu. Tato pluralita je nicméně dezintegrovaná a nefunkční. Teprve zásahem

68 Zde i dále je grafická slovní hříčka mezi „povstáním“ ve smyslu vzniku a ztopořením stvořitelova pohlavního údu.

69 Všimněme si, že text mluví o „třech“ entitách, ačkoliv společně s okem je celkový součet čtyři, tj. oko není započítáno jako entita, ale je vnímáno jako zosobněný vztah mezi monádou a prvotní dyádou. 
jiné jeho tělesné části, oka zastupujícího ženský princip, dochází k reintegraci jednotlivých částí a k jejich následné aktivaci. Mediační role oka je zdůrazněna takto:

Poté, co se oko navrátilo, zjistilo, že jeho místo bylo zaplněno, a rozezlilo se. Bylo nahrazeno Zářivou (ureem). Umístil jsem proto (oko) na své čelo. ${ }^{70}(27,3-4)$

Předešlý text charakterizuje ambivalentní povaha, jež je pro mediátory nejrůznějšího druhu typická. Na jednu stranu mají schopnost spojovat to, co bylo odděleno. Na druhou stranu moc, která toto umožňuje a kterou mediátorka disponuje, je naprosto nekontrolovatelná, a proto i velice nebezpečná (oko se rozezlilo). Mediátorka do struktur částečně nepatř́i (oko bylo od Pána veškerenstva odděleno), zároveň má ovšem na strukturu pevnou vazbu (je to oko Pána veškerenstva a následně je opět integrováno v podobě kobry, která je umístěna na čele božstva/faraona).

O stvořitelově oku proto můžeme uvažovat jako o principu spolupodílejícím se na aktu samotného stvoření (Atum tvoří oko, které zároveň v Atumovi tvoří organizovaný svět), stejně jako se z gnostického textu dozvídáme o této roli (Paní) hromu (,Já jsem matkou svého otce a sestrou svého muže, / a on je můj potomek“; 13,31-32). ${ }^{71}$ Právě schopnost integrovat protikladné principy je to, $\mathrm{z}$ čeho oko/bohyně coby prostředník čerpá sílu. Stejně tak i moc (Paní) hromu je v celém textu popisována právě v této ambivalentní poloze. V rámci staroegyptské náboženské spekulace přitom byly všechny významné bohyně zcela běžně s okem boha stvořitele ztotožňovány. Nejvýrazněji je to vidět na příkladu teologických koncepcí v rámci kultu tzv. Velkých bohyň.

\section{Kulty Velkých bohyň}

V řecko-římském období je doloženo množství chrámů, v nichž kult ženských božstev hrál zcela klíčovou úlohu. Jedním z nich je například chrám bohyně Hathor v Dendeře. ${ }^{72}$ Chrám zažil intenzivní období výstavby jak v době ptolemaiovské, tak i během vlády Tiberia (14-37 po Kr.)

70 Tato pasáž odkazuje na další projev božského oka, kterým byl ureus (kobra) na čele faraona. Destruktivní síla, kterou oko disponovalo, tak byla transformována a využita na ochranu panovníka/božstva. K diskuzi ohledně tohoto tématu viz např. Lana Troy, Patterns of Queenship in Ancient Egyptian Myth and History, Uppsala: Gustavianum 1986, 23-25.

71 Tento autogenetický aspekt je v rámci egyptské metaforiky zobrazen i skrze cyklus slunce, jež každý večer vstupuje/oplodňuje bohyni Nut, symbolizující nebe, aby se nadcházející ráno zrodilo jako její syn.

72 Pro přehled symboliky spojované s bohyní Hathor viz Philippe Derchain, Hathor quadrifrons: Recherches sur la syntaxe d'un mythe égyptien, Istanbul: Nederlands Historisch-Archaeologisch Inst. in het Nabije Oosten 1972; brilantně sepsaná práce je 
a Nerona (54-68 po Kr.). V rámci celého komplexu je pro nás zajímavá zejména výzdoba tzv. vabetu ${ }^{73}$ („,̌cistého [místa]“) - otevřené kaple s vyvýšeným kultovním prostorem umístěné u vstupu na schodiště vedoucí na střechu chrámu. Vabet byl klíčový během slavností Nového roku, kdy docházelo k rituálnímu spojení kultovních soch se sluncem. Reliéfní výzdoba zpodobňuje celkem deset postav přinášejících koruny coby dar pro bohyni Hathor v podobě její nejdůležitější manifestace „Paní Dendery, Reova oka, Paní nebe, Vládkyně všech bohư“. První v řadě božstev je Thovt dvakrát veliký (Dismegistos), pán Hermopole. Za ním je seřazena hermopolská Ogdoáda, tedy Naunet a Nun (Pravodstvo), Hehet a Heh (Nekonečná rozlehlost), Keket a Kek (Temnota) a Nauet a Nau (Propast) ve své tradiční podobě postav s hadími (ženská božstva), respektive žabími (mužská božstva) hlavami. Jako poslední v řadě stojí faraon, nabízející Hathoře korunu hepet, jež symbolizuje vládu nad Egyptem.

Jak vysvětlují F. Coppens a J. Janák, volba právě těchto božstev a korun má za cíl zdůraznit tři hlavní aspekty Hathořiny manifestace: (1) primordiální charakter; ${ }^{74}$ (2) asociaci se sluncem, respektive bohem Re, tedy s aspektem stvoření; (3) nadvládu nad stvořeným světem („Královna Horního a Dolního Egypta“, „Veliký Nun/Pravodstvo jí drží koruny“ atd.). ${ }^{75}$ Hathořin primordiální aspekt je zdůrazněn právě přítomností samotné Ogdoády a boha Thovta - božstev, která podle hermopolské a memfidské tradice hrála klíčovou úlohu během stvoření světa. Výmluvný je Hathořin titul „Prvotně původní, pocházející z věčného/velikého Pravodstva“, případně „Dcera (hada) Irty, který vzniknul na počátku ... Paní nebe, země, zásvětí, vod a hor“. Největší množství epitet ovšem spojuje Hathoru s Reem - stvořitelským bohem slunce. Hathor je „Velká kráva Ihet, která zrodila Rea“, zároveň je ale považována za jeho dceru, která s ním sdílí jeho solární aspekty. Oba jsou tedy ve vzájemném vztahu stvořenosti: Re stvořil na počátku Hathoru, která následně přebrala iniciativu a stvořila vše ostatní („,Ta, která umožňuje projevení/stvoření lidí a bohů“). Všechny tyto aspekty kladou bohyni Hathor do centra chrámového kultu

Alison Roberts, Hathor Rising: The Serpent Power of Ancient Egypt, Totnes: NorthGate Publishers 1995.

73 Dieter Arnold - Sabine H. Gardiner - Helen M. Strudwick - Nigel C. Strudwick, The Encyclopedia of Ancient Egyptian Architecture, Cairo: American University in Cairo Press 2003, 255; Filip Coppens, The Wabet: Tradition and Innovation in Temples of the Ptolemaic and Roman Period, Prague: Charles University in Prague 2008.

74 K tomuto Hathořinu aspektu viz též René Preys, „Hathor, fille de Noun: Créateur et démiurge dans le temple de Dendara“, Revue d'Égyptologie 57, 2006, 199-215.

75 Filip Coppens - Jiří Janák, „The Ogdoad and Divine Kingship in Dendara“, in: Filip Coppens - Jiří Janák - Hana Vymazalová (eds.), Royal versus Divine Authority: Acquisition, Legitimization and Renewal of Power: $7^{\text {th }}$ Symposium on Egyptian Royal Ideology (Prague, June 26-28, 2013), Wiesbaden: Harrassowitz 2015, 83-94: 86-87. 
a oslavují ji v roli stvořitelské a vládnoucí. Zároveň nesmíme zapomínat, že Hathor, stejně jako ostatní egyptské bohyně, byla primárně vnímána ve své podobě oka boha stvořitele (Re/Atuma). S tím byly přitom asociovány všechny paradoxní výpovědi o její roli prostřednice tak, jak jsme viděli $\mathrm{v}$ předešlé kapitole.

Ještě explicitnější výpověd’ ohledně stvořitelské (a tedy i paradoxní) role další z Velkých bohyň, Neit, je obsažena v invokačních textech v chrámu v Esně (Invokace 5, 7-11 [Esna 216.2]):

Neit, Prvotní vodě, která dala povstat zemi; Neit, povstávající, která stvořila toho, který stvořil zemi (had Irta); Neit, Muži, který stvořil Ženu; Neit, Ženě, která stvořila Muže; Neit, vodě, která dala povstat času (v aspektu) věčného opakování; Neit, záplavě, která dala povstat času (v aspektu) věčné stálosti. ${ }^{76}$

Poměrně explicitní je i hymnus datovaný do vlády císaře Trajána [Esna 317.1-2]:

Je to (Neit) ženský Předek, který byl na počátku, / ženský Pravzor, samozplozenec, / první Matka, ureus „Toho, jehož jméno je skryto“ [tj. Amona], / bůh a bohyně, / bohyně, která jedná (jako) bůh [tj. plodí autoerotickým aktem]. ${ }^{77}$

Nejen z nápisů z vabetu bohyně Hathor, ale i z těchto pár vybraných nápisů z chrámu bohyně Neit, je vidět nejen důležitost, kterou staroegyptští kněží přikládali těmto konkrétním bohyním v rámci svých teologických systémů, ale zároveň spatřjueme i mnohé podobnosti s motivy z gnostických textů.

\section{Shrnutí: Paralely mezi gnostickými ženskými bytostmi a staroegyptskými Velkými bohyněmi}

Ve stručnosti si tedy výše předestřené podobnosti shrňme do následujících sedmi charakteristik. Jak (Paní) hromu, případně jiné významné ženské postavy gnostických textů (Sofia, Barbeló, Protennoia), tak staroegyptské Velké bohyně (Hathor, Neit, Eset):

1) hrají roli stvořitelského, primordiálního božstva, jež dalo povstat základním principům světa;

76 Serge Sauneron, Les fêtes religieuses d'Esna aux derniers siecles du paganisme, Caire: Institut Français d'Archéologie Orientale 1962; Emanuele M. Ciampini, „,Magic in the Sign: Iconic Writings in the Litany of Neith at Esna and the Performative Nature of the Divine Name [Esna 216.1-4]“, in: Grażyna Bąkowska-Czerner - Alessandro Roccati - Agata Świerzowska (eds.), The Wisdom of Thoth: Magical Texts in Ancient Mediterranean Civilisations, Oxford: Archaeopress 2015, 15-22: 16-18.

77 E. M. Ciampini, „Magic in the Sign...“, 18. 
2) jsou ve vztahu vzájemné stvořenosti s mužskou stvořitelskou božskou entitou/světem; ${ }^{78}$

3) coby stvořitelky mají androgynní/gynandrický charakter, případně plodí samy v sobě autoerotickým aktem; ${ }^{79}$

4) jsou často asociovány s hadem - symbolem jejich primordiálního aspektu, který sdílejí s mužskými postavami stvořitele ${ }^{80}$

5) jimi stvořenému světu i vládnou - jejich „moc“ je přitom z mužské perspektivy paradoxně bezmocná; ${ }^{81}$

6) mají schopnost propojovat protikladné principy a skrze tuto svou schopnost působit v roli (spasitelských) prostřednic; ${ }^{82}$

7) androcentrickou optikou, jež formovala symbolický systém tehdejší společnosti, jsou tyto mocné ženské postavy silně ambivalentní, a tudíž znepokojivé, nebot vládnou ničivou/tvořivou silou. ${ }^{83}$

Jak bylo uvedeno $\mathrm{v}$ jedné $\mathrm{z}$ anonymních recenzí tohoto textu, je otázka, zda výše uvedené charakteristiky nejsou natolik obecné, že by se mohly týkat jakéhokoliv náboženského systému (nejen) starověkého Středomoří, jenž obsahuje výrazné ženské božské postavy. Zběžný pohled na mytologii starověkého Řecka, systému nejrelevantnějšího pro diskutované téma, přitom potvrzuje relevanci této námitky ve vztahu k charakteristikám pět až sedm (paradoxnost, a tudíž i znepokojivý charakter moci bohyň, projevující se zejména jejich schopností propojovat protiklady). J.-P. Vernant například o bohyni Artemis hovoří takto: „... vždy působí jako božstvo spojené s hranicemi. Artemidina obojetná moc, umožňující přechody mezi divošským a kulturním, ustavuje tuto hranici právě skrze akty jejího pře-

78 Barbeló a Sofia ve vztahu k nejvyššímu bohu, pozemskému i nebeskému Adamovi, popřípadě nebeskému Kristu.

79 Napřr. Protennoia ve třech tvarech (NHC XIII,1: 45,1-4); Evangelium Egyptanů (NHC IV,2: 61,25-62,1).

80 Pravodstvu Nun je ve staroegyptských pramenech často připisována podoba hada; egyptská bohyně plodnosti Isis Ermúthis, jejíž kult byl v Egyptě velice rozšířený (společně s Isidou a Serapidem), byla tradičně zobrazována s hadím tělem; v gnostickém korpusu doloženo např́iklad pro Sofii Zoé (duchovní ženu) v Podstatě archontů (NHC II,4: 89,31-90,1), popř́ipadě v Tajné knize Janově (NHC II,1: 10,8-10), kde Sofie porodí hadí bytost se lví tlamou.

81 Ženské postavy vládnou v jakémsi ,vyhnanství“" na zemi, jež je asociována s pohybem, špínou a utrpením a kontrastována s nehybným, klidným a stabilním božstvím mužským.

82 (Paní) hromu skrze paradoxní výroky, jež o sobě pronáší, Hathor/Neit z pozice úzké asociace s okem boha Re - zosobněním vztahu mezi druhou/třetí božskou generací symbolizovanou systémem binárních opozic (muž $\times$ žena; nebe $\times$ země; suchý $\times$ vlhký).

83 Viz paradoxní výpovědi (Paní) hromu, s. 58. 
kračování. “84 Artemis byla proto asociována zejména s iniciačními rituály dospělosti u dívek i chlapců, tedy s okamžikem, kdy jednotlivci přecházejí ze stavu „divokého mládí“ do stavu „kulturní dospělosti“ (dívky se proměňují v manželky a následně $\mathrm{v}$ matky, chlapci v politicky aktivní členy obce a válečníky). ${ }^{85}$ Podobně i Afrodíté můžeme vnímat jako liminální postavu, jež prostředkuje mezi řadou protikladných kategorií, ${ }^{86}$ stejně jako Démétér, jak ukazuje např́klad mnohovýznamová symbolika řeckého rituálu Thesmoforií, jehož ústředním motivem byly různé modality společenské kategorie plodnosti. ${ }^{87}$ Takto bychom mohli pokračovat i u dalších řeckých bohyň a ukázat jejich transgresivní a prostředkující aspekty, podobně jako jsme je identifikovali v případě ženských postav staroegyptských a gnostických. Jak jsem se snažil ukázat výše, společné mají tyto systémy to, že politická moc byla $\mathrm{v}$ jejich rámci primárně asociována s mužskou částí populace, což, zjednodušeně řečeno, následně založilo právě toto pojetí transgresivního, na veřejné moci nezávislého, a tudíž (pravidly moci) neomezeného ženského božství. Do svého textu jsem téma začlenil proto, že je zásadní pro porozumění kulturnímu kontextu oněch podle mého názoru zcela původních staroegyptských aspektů gnostického ženského božství, tedy charakteristiky jedna až čtyři, na které se podíváme nyní.

Recká tradice pracovala s auto-, respektive parthenogenetickými aspekty ženských postav, které dokázaly tvořit (potomstvo) bez přispění mužského protějšku (charakteristiky jedna a tři): nejen primordiální bohyně Nyx (stvořila abstraktní koncepty spojené se smrtí a spánkem) ${ }^{88}$ a Gé/Gáia (stvořila kromě jiného i svého partnera Úrana), ${ }^{89}$ ale například i Héra (stvořila Área a Héfaista). ${ }^{90}$ Parthenogenetické aspekty jde podle

84 Jean-Pierre Vernant, Mortals and Immortals: Collected Essays, ed. Froma I. Zeitlin, Princeton, NJ: Princeton University Press 1991, 204 (překlad autor).

85 Ibid., 195-257; Stephanie Lynn Budin, Artemis, London - New York: Routledge 2016.

86 Paul Friedrich, The Meaning of Aphrodite, Chicago - London: University of Chicago Press 1978, 131-148.

87 Radek Chlup, „The Semantics of Fertility: Levels of Meaning in the Thesmophoria“, Kernos 20, 2007, 69-95.

88 Hésiodos (Th. 211-232); pro další odkazy viz Marguerite Rigoglioso, Virgin Mother Goddesses of Antiquity, New York: Palgrave Macmillan 2010, 16-18.

89 Hésiodos (Th. 126-132); M. Rigoglioso, Virgin Mother Goddesses..., 18-21.

90 M. Rigoglioso, Virgin Mother Goddesses..., 65-97. Héfaistos je sice Homérem prezentován jako syn Dia a Héry (Il. 1578; Od. 8.312), Hésiodos (Th. 927-928) a další autoři ovšem připisují rodičovství Héře samotné. Arés měl podle Homéra (Il. 5.896) i Hésioda (Th. 923) rodiče dva (Zeus, Héra), zároveň se ovšem Zeus v Il. 5.890-893 od svého syna distancuje a prohlašuje ho čistě za syna Héry. Tento motiv zajímavě rozvedl Ovidius (Fasti 5.193-260), podle něhož byl Arés stvořen parthenogeneticky Hérou. Ačkoliv v řeckém materiálu pro toto neexistuje předloha, Danielle Porte, „La fleur d'Olène et la naissance du dieu Mars“, Latomus 42/4, 1983, 877-884, se domnívá, že 
M. Rigoglioso rozeznat i u dalších bohyní, například Athény/Neit/Métidy, ${ }^{91}$ Artemidy ${ }^{92}$ a Démétér s Persefonou. ${ }^{93}$ Ačkoliv jsou tyto bohyně zcela integrální součástí klasického řeckého panteonu, Rigoglioso ve svých textech přesvědčivě ukazuje, že byly řeckými autory $\mathrm{v}$ různých obdobích opakovaně asociovány právě se severní Afrikou (zejména ve spojení s Amazonkami a Libyí), respektive specificky s Egyptem (zejména postava Athény/Artemis s egyptskou bohyní Neit). ${ }^{94}$ Ačkoliv z této skutečnosti rozhodně nijak automaticky nevyplývá egyptský/africký původ řecké parthenogenetické koncepce samotné, rozhodně bylo pro Reky přirozené kategorii „,vnitřní jinakosti“ parthenogenetických schopností bohyň vyjadřovat i skrze geografický kód právě asociací s Egyptem, archetypálním „,Světem naruby“.95

Oproti tomu v Egyptě samotném nebyly tyto koncepce prezentovány jako „cizí“ anebo ,převrácené“, přímo naopak. Pokud by tedy byly parthenogenetické aspekty gnostických textů převzaty z tradice řecké, dá se očekávat, že by si zachovaly i onen ústřední charakter „,izosti““. Tak tomu ale není. Naopak je v gnostických textech rozeznatelná perspektiva egyptská, podle níž je parthenogenetická schopnost primordiálních ženských postav integrální součástí jejich charakteru, vedle mnoha dalších aspektů. Navíc oproti řeckému modelu, který zdůrazňuje schopnost dané bohyně plodit nezávisle na mužském principu, je v Egyptě, stejně jako v gnostických textech, kladen důraz na propojeni aspektu mužského a ženského $\mathrm{v}$ jeden celek skrze koncepci androgynie/gynandrie, jež naopak v řeckých textech v tomto rozsahu schází (viz i diskuze v Závěru). V řeckých pramenech proto následně absentuje i motiv vzájemné stvořenosti mužského a ženského primordiálního principu (charakteristika číslo dvě), zatímco v textech egyptských je tato koncepce zcela zásadní.

Poslední, čtvrtá, charakteristika se týká asociace primordiálních postav s hady. Řecká tradice spojuje hady s autochtonními postavami (Kekrops, Erichthonios ad.), tyto jsou ovšem vždycky pohlaví mužského. Gaia/země

Ovidiova verze by mohla vycházet z původního, nedochovaného řeckého vzoru. Za tyto odkazy děkuji Radku Chlupovi.

91 M. Rigoglioso, Virgin Mother Goddesses..., 23-50.

92 Ibid., 51-64.

93 Ibid., 99-189.

94 Ibid., 36-44.

95 Hérodotos (Hist. 2.35-36): „Právě tak, jako mají Egyptané nad sebou jinou oblohu a jako jejich řeka má jiné vlastnosti nežli ostatní řeky, tak také si ve všem všudy ustanovili opačné obyčeje a zákony, než mají jiní lidé. Ženy u nich chodí na trh a obchodují a muži zůstávají doma a tkají ... Muži nosí břemena na hlavách, ženy na ramenou; ženy močí vestoje, kdežto muži vsedě ... Řekové píší a počítají pomocí kaménků od levé strany doprava, Egyptané však odprava doleva, a přitom tvrdí, že postupují směrem doprava, kdežto Řekové prý doleva ..." (Hérodotos, Dějiny: Aneb devět knih dějin nazvaných Músy, trans. Jaroslav Šonka, Praha: Odeon 1972, 112-113). 
je sice opakovaně líčena jako matka či místo původu mytických hadích postav anebo hadů obecně, ${ }^{96}$ hadí podobu jako takovou na sebe ovšem berou primordiální ženské postavy pouze v tradici egyptské.

Pokud do této diskuze zahrneme i formální podobnosti mezi skladbou Hrom a tzv. Isidinými aretalogiemi (,Já jsem...“), domnívám se, že minimálně v případě Hromu je relevantní uvažovat o zásadním vlivu staroegyptských náboženských koncepcíi. ${ }^{97}$ Jak jsem se přitom snažil ukázat na rozboru paralel mezi Eirénaiovým pojednáním a Chonsuovou kosmogonií, staroegyptské motivy je možné rozeznat i ve více „mainstreamových“" gnostických systémech. V tomto kontextu je důležitá i skutečnost, že spis Protennoia ve třech tvarech (nyní řazený do NHC XIII), tedy jeden z možných vzorů jiné relevantní části Eirénaiova pojednání (kapitoly 29), byl původně vložený $\mathrm{v}$ podobě volných listů do předních desek vazby kodexu NHC VI, který obsahoval i Hrom. ${ }^{98}$ Ačkoliv nemůžeme vyloučit náhodu, je stejně důvodné se domnívat, že tyto skladby byly ve starověku považovány za tematicky provázané. ${ }^{99}$ Mnoho interpretů sice hledá paralely ve stoických a platónských koncepcích, ${ }^{100}$ podle mého názoru bychom ovšem měli brát podobně vážně i možný vliv autochtonní staroegyptské tradice.

96 Plútarchos (Moralia 637B) např́íklad tvrdí, že myši (v Egyptě), hadi, žáby a cikády se rodí přímo ze země; podobně i Hérodotos (Hist. 1.78) hovoří o hadech jako zrozených ze země. Podle pozdější tradice dochované u Ovidia (Metamorph. 1.438-440), Gé/Gaia po skončení potopy světa stvořila Pýthóna, hada/draka střežícího věštírnu v Delfách.

97 V této souvislosti je zajímavé poukázat na formulaci z Hrom 14,8: „Já jsem oporou moci v jeho mládí / [a] on je holí mého stáří“ (viz výše, s. 58). Jak se dozvídáme z tzv. staroegyptských „naučení“ (např. Ptahotepovo: Miriam Lichtheim, Ancient Egyptian Literature: A Book of Readings I, Berkeley: University of California Press 1973, 6180), souboru rad sestavovaných seniorními členy administrativy pro své nástupce, případně z autobiografických nápisů (Usir-Amon: Eberhard Dziobek, Denkmäler des Vezirs User-Amun, Heidelberg: Heidelberger Orientverlag 1998), „hůl stáří“ byl ve starém Egyptě administrativní titul jakéhosi asistenta prominentních egyptských hodnostářu. Velice často tato funkce připadla vlastnímu synovi daného úředníka, což mělo umožnit hladké předání správních povinností z otce na syna. V případě Hromu vidíme zajímavou inverzi, která souzní s paradoxním charakterem celého textu - stvořitel, tedy „služebně starší“ člen „kosmické administrativy“, je pasován do role nástupce (Paní) hromu, jež mu ovšem zároveň sloužila jako tatáž opora „,v jeho mládí“. K úřradu „,hole stáří “ viz např. Rosalind Janssen - Jac Janssen, Getting Old in Ancient Egypt, London: The Rubicon Press 1996.

98 Rozeznatelné na fotografii v James M. Robinson et al. (eds.), The Facsimile Edition of the Nag Hammadi Codices: Codex VI, Leiden: E. J. Brill 1972, 3.

99 Názory na provázanost těchto textů se samozřejmě rozcházejí, ačkoliv většina badatelů míru jejich formální a obsahové podobnosti nějakým způsobem reflektuje. Pro přehledné shrnutí celé diskuze viz T. B. Halvgaard, Linguistic Manifestations..., 41-45.

100 T. B. Halvgaard, Linguistic Manifestations... 


\section{Závěr}

$\mathrm{V}$ předešlých odstavcích jsem se pokusil kromě přehledu motivických podobností mezi gnostickými a staroegyptskými koncepcemi nastínit i klíčovou úlohu, kterou v rámci staroegyptského náboženství hrály právě Velké bohyně. Jakým způsobem ovšem mohlo dojít k rožšiření těchto sofistikovaných kněžských nauk do obecného povědomí gnostiků? Během řecko-římského období došlo v Egyptě k masivnímu rozšíření náboženských poutí, jichž se začali účastnit i lidé neegyptského původu (jakýsi náboženský turismus). ${ }^{101}$ Ačkoliv součástí staroegyptského náboženství byly vždy průvody, během nichž božstva ,vycházela“ ze svých svatyní, aby interagovala $\mathrm{s}$ věřícími mimo chrámové zdi, v řecko-římské době dosáhla návštěvnost svatyní nebývalých rozměrů. Tyto př́iležitosti $\mathrm{k}$ veřejnému veselí, jehož se podle dobových svědectví údajně účastnily desítky tisíc lidí, ${ }^{102}$ a chrámovému turismu tak vytvářely ideální kontext pro propagaci teologického obsahu kultu daných božstev, a to i mezi „gnostiky“, kteří v Egyptě žili, působili a pravděpodobně se těchto slavností i účastnili. ${ }^{103}$ A jak jsme viděli výše, původní egyptská teologická spekulace přitom nebyla vůbec za zenitem, práě naopak. ${ }^{104}$

Ačkoliv předešlá úvaha by mohla být zcela soběstačným vysvětlením, na závěr si dovolím ještě jednu, odvážnější, spekulaci, jež navazuje na koncepci androgynie/gynandrie. Někteří komentátoři zdůrazňují společensky disociační, respektive alienační akcent obsažený v gnostických textech. ${ }^{105}$ Gnostičtí autoři a komunity, pro které byly texty psány, ,,sami sebe opakovaně označovali jako ,cizí‘ ve vztahu k proto-ortodoxní církvi a (ob-

101 Viz například David Frankfurter, „Introduction“, in: id. (ed.), Pilgrimage and Holy Space in Late Antique Egypt, Leiden - Boston - Köln: Brill 1998, 3-48; id., Religion in Roman Egypt: Assimilation and Resistance, Princeton: Princeton University Press 1998, zejm. 171-174, 190-191, 218-219; id., ,Religion in Society: Graeco-Roman“, in: Allan B. Lloyd (ed.), A Companion to Ancient Egypt, Chichester: Wiley-Blackwell 2014, 526-546.

102 Hérodotos ve svých Dějinách (II, 60) při popisu slavností bohyně Neit (v jeho interpretatio graeca bohyně Artemis) ve městě Busiris uvádí účast až sedmi set tisíců mužů a žen (s výjimkou dětí). Ačkoliv je to číslo jistě přehnané, svědčí o masivní účasti populace na těchto svátcích.

103 Viz též T. Gaston, „The Egyptian Background...“, 403.

104 Viz třeba tzv. Knihu Thovtovu (Richard Jasnow, „Between Two Waters: The Book of Thoth and the Problem of Greco-Egyptian Interaction“, in: Ian Rutherford [ed.], Greco-Egyptian Interactions: Literature, Translation, and Culture, 500 BCE-300 CE, Oxford: Oxford University Press 2016, 317-356). Theogonické koncepce obsahují i řecké magické papyry (Papyri Graecae Magicae [PGM VII.II.516-521]), které se dokonce přímo zmiňují i o hermopolské Ogdoádě (PGM III.145; XXI).

105 Viz např. Hans Jonas, The Gnostic Religion: The Message of the Alien God and the Beginnings of Christianity, Boston: Beacon Press 1970. 
vykle) i vůči většinové řecko-římské společnosti““.106 J. Cahana si všímá, že gnostické skupiny pro konceptualizaci této jinakosti užily právě kategorii oboupohlavnosti, ${ }^{107}$ na jejíž velice negativní vnímání v řecko-římské společnosti poukazují např́íklad L. Brisson a J. Lloyd. ${ }^{108} \mathrm{~V}$ důsledku automatické asociace pohlaví (biologické danosti) s genderem (tj. kulturně konstruovanou rolí pro muže a ženy) ${ }^{109}$ kategorie androgynů zásadním způsobem problematizovala společenské rozdělení, protože mísila zavedené společenské kategorie (muž-aktivní a žena-pasivní), které se promítaly do všech oblastí společenské struktury od lékařství po řízení obcí a státu. Podle Cahana gnostikové ,využili tento marginalizovaný, a někdy i přímo opovrhovaný, koncept ,jiného“ a postavili ho do popředí“ ${ }^{110}$ Ačkoliv tento výklad v sobě zjevně obsahuje silnou projekci současných neoliberálních hodnot, dobře ilustruje sílu symbolického potenciálu, který tento materiál stále nabízí.

Jak jsem se snažil ukázat v této studii, sexuální a androgynní symbolika byla v původním staroegyptském teologickém diskurzu ve vztahu ke kosmogonickým obrazům propracovaná již několik tisíciletí před vznikem „gnosticismu“ jako takového. Podle všeho se zdá, že gnostici toto symbolické ovoce staroegyptského myšlení, jež se jim v Egyptě nabízelo na každém kroku, utrhli a s chutí si na něm pochutnali.

106 Jonathan Cahana, „Androgyne or Undrogyne: Queering the Gnostic Myth“, Numen 61, 2014, 509-524: 510-511.

107 J. Cahana, „Androgyne or Undrogyne...“.

108 Luc Brisson - Janet Lloyd, Sexual Ambivalence: Androgyny and Hermaphroditism in Graeco-Roman Antiquity, Berkeley: University of California Press 2002.

109 Viz např. David M. Halperin, One Hundred Years of Homosexuality: And Other Essays on Greek Love, Hoboken: Taylor and Francis 2012, 23.

110 J. Cahana, ,Androgyne or Undrogyne...“, 521. 


\title{
SUMMARY
}

\section{"Tis I, Mother of My Father": The Feminine Principle and Ancient Egyptian Religious Motifs in Gnosticism}

This essay argues that scholarship on gnostic texts could strongly benefit from taking into greater account elements of autochthonous ancient Egyptian religious concepts when interpreting gnostic intellectual and ritual systems. The central argument focuses on conspicuously similar roles and characteristics of female characters in both gnostic and ancient Egyptian symbolism, as witnessed especially within the Egyptian theological and ritual traditions of the so-called Great Goddesses (Isis, Neith, and Hathor). As these immensely popular cults were contemporaneous with the presumed development of various gnostic systems, this essay argues for a direct Egyptian - gnostic influence. The textual analysis focuses on a comparison of Chapter 30 of the Adversus haereses of Irenaeus of Lyon (with appropriate references to original gnostic concepts and texts) with an Egyptian cosmogonic myth located in the temple of Khonsu in Karnak, proceeding then to the analysis of select passages of NHC VI,2 (The Thunder: Perfect Mind). The essay argues that in both ancient Egyptian and gnostic sources, female characters are described as: (1) primordial deities, creators of elementary principles governing creation; (2) being in a mutual relationship of createdness with a divine male creative principle/the world; (3) androgynous/gynandrous, begetting through some type of autoerotic activity; (4) taking on primordial serpentine forms; (5) rulers of the created world; (6) mediators with the ability to connect opposing principles; (7) ambivalent and - from the androcentric optics of these symbolic systems - as possessing deeply troubling, creative/destructive abilities. These ancient Egyptian concepts would have been disseminated among Gnostics living in Egypt - for example, during the massively popular public festivals of the various Great Goddess cults at their ritual centres at Phylae, Dendera, Edfu, and Saïs.

Keywords: ancient Egyptian religion; gnosis; Great Goddesses; female characters as mediators; Khonsu Cosmogony; Nag Hammadi codices.

\author{
Department of Philosophy and Religious Studies \\ Faculty of Arts \\ Charles University \\ Nám. Jana Palacha 2 \\ 11638 Prague 1 \\ Czech Republic
}

MARTIN PEHAL

martin.pehal@ff.cuni.cz 